\title{
ДИСкУССиИ
}

DOI: https://doi.org/10.15688/jvolsu2.2019.2.18

UDC 81'42:27-235

Submitted: 16.10 .2018

LBC 81.055 .1

Accepted: 10.04.2019

\section{ATTEMPTS TO DESCRIBE GOD AND DIVINE CATEGORIES IN A GENDER-NEUTRAL WAY IN THE MODERN FEMINIST LINGUISTIC DISCOURSE}

\author{
Konstantin S. Sharov \\ M.V. Lomonosov Moscow State University, Moscow, Russia
}

\begin{abstract}
The article is devoted to the study of feminist linguistic concepts in which attempts are made to re-think the category of divinity. We study gender-neutral (inclusive) versions of English translations of the Bible that depict God not as the Father but as Father and Mother in the heaven. We also investigate quotations from classical versions of the Bible that use the model of imagining God in female terms (e. g., a mother, a nurse, a woman giving birth). The purpose of the paper is to study of feminist preferences is linguistic techniques of the Bible translation into English; to find out to what extent the results of such technique implementations are adequate from the point of view of the classical linguistic-theological approach; to define the limits to which these results are valuable for the linguistic analysis of sacred texts. The research methodology includes a contextual analysis method, comparative, structural, comparative historical methods. For comparison with gender-neutral versions of the Bible, quotations from classical translations are studied: the original edition of the English King James's Bible of 1611, the Elizabethan Russian Slavonic Bible of 1751, the Synodal Russian Bible of 1876 and the Hebrew Masoretic text of the Tanakh. It is shown that, from a linguistic view, God is beyond the gender field and is not traditionally described in the categories of male or female natural gender (sex). It is established that the comparison of God in the classical versions of the Bible with a woman, is no more than a conventional linguistic procedure that does not testify the essentialist feminist nature of the divine. It is concluded that despite high attractiveness and usefulness of feminist discourse in modern times, the academic Christian theology, history of confessions and religious linguistics cannot accept the idea of God as a Creature embodying the two polar gender principles (male and female). Similarly, gender-neutral English translations of the Bible should not be recognised nor accepted by the scientific and Church communities as an Anglican canon.

Key words: gender-neutral Bible, politically correct Bible, feminism, linguistic description of God, English Bible, Masoretic text, Septuagint, Russian Slavonic Bible.

Citation. Sharov K.S. Attempts to Describe God and Divine Categories in a Gender-Neutral Way in the Modern Feminist Linguistic Discourse. Vestnik Volgogradskogo gosudarstvennogo universiteta. Seriya 2. Yazykoznanie [Science Journal of Volgograd State University. Linguistics], 2019, vol. 18, no. 2, pp. 204-216. (in Russian). DOI: https://doi.org/10.15688/jvolsu2.2019.2.18
\end{abstract}




\title{
ГЕНДЕРНО-НЕЙТРАЛЬНОЕ ОПИСАНИЕ БОГА И КАТЕГОРИЙ БОЖЕСТВЕННОСТИ С ПОЗИЦИЙ ФЕМИНИСТСКОГО ЛИНГВИСТИЧЕСКОГО ДИСКУРСА
}

\author{
Константин Сергеевич Шаров \\ Московский государственный университет им. М.В. Ломоносова, г. Москва, Россия
}

\begin{abstract}
Аннотация. Статья посвящена изучению феминистских лингвистических представлений, в рамках которых предпринимаются попытки переосмыслить категории божественности. Исследуются гендерно-нейтральные (инклюзивные) версии английских переводов Библии, где Бог изображается не как Отец, а как Отец и Мать на небесах. Анализируются фрагменты Библии, в которых использованы приемы воображения Бога в категориях женского (мать, кормилица, роженица). Целью является изучение лингвистических техник переводчиков Библии на английский язык, работающих в рамках феминистского дискурса; установление того, насколько адекватными будут результаты применения подобных техник с точки зрения классического лингвистико-богословского подхода и до какой степени эти результаты ценны для лингвистического анализа священных текстов. Показано, что с лингвистической точки зрения Бог находится за пределами гендерного поля и не описывается в категориях мужского или женского натурального гендера (пола). Установлено, что в Библии сравнения Бога с женщиной - условность, языковой прием, не свидетельствующий об эссенциалистской феминной сущности божественного. Делается вывод, что, несмотря на высокую привлекательность и полезность феминистского дискурса в современности, академическое христианское богословие, история конфессий и религиозная лингвистика не могут принять представление о Боге как о Существе, воплощающем в Себе два полярных гендерных начала (мужское и женское), а гендерно-нейтральные английские переводы Библии не должны признаваться научным и священным сообществом в качестве англиканского канона.

Ключевые слова: гендерно-нейтральная Библия, политически корректная Библия, феминизм, лингвистическое описание Бога, английская Библия, масоретский текст, Септуагинта, церковнославянская Библия.
\end{abstract}

Цитирование. Шаров К. С. Гендерно-нейтральное описание Бога и категорий божественности с позиций феминистского лингвистического дискурса // Вестник Волгоградского государственного университета. Серия 2, Языкознание. -2019. - Т. 18, № 2. - C. 204-216. - DOI: https://doi.org/10.15688/jvolsu2.2019.2.18

\section{Введение}

В настоящее время в рамках феминистского дискурса осуществляется неолиберальная критика традиционных переводов Библии как патриархально-ориентированных, доносящих антиженские дискриминирующие смыслы до читателей; причем неважно, являются эти читатели верующими или нет [An Inclusive Language Lectionary, 1985; Bibel in gerechter Sprache, 2006; Harrelson, 1991; Jacobs, 2001; Walsh, 1999]. С конца 1970-х гг. до наших дней появилось несколько десятков версий так называемых гендерно-нейтральных (инклюзивных) переводов христианского Священного Писания, в которых предприняты попытки заменить обычный, гендерно-специфичный язык, новым [Brenner, Fontaine, 2001, p. 7; Gomola, 2010, p. 193]. Существенная часть феминистских изменений касается английских переводов священных текстов [Kittel, Friedrich, 2003, p. 22]. Мы находим этому две причины: 1) английские переводы Библии самые многочисленные в мире; 2) английский язык в большей степени связан с дискурсом политкорректности, который сегодня доминирует в странах англоговорящего мира.

Гендерно-нейтральный перевод отражает не столько попытки создать наиболее адекватный перевод Священного Писания, сколько переосмысление самого библейского послания. Например, С. Шольц говорит, что написанные на инклюзивном языке версии Библии должны не только устранять маскулинную лексику, грамматику и смыслы, но и внедрять эгалитарные и неиерархические концепты, трансформировать языковые структуры, посредством которых выражены любые 
виды дискриминации (сексистская, расовая, классовая), убирать все фрагменты, отсылающие к физической инвалидности людей и их ментальной ограниченности, а также реферирующие к националистическим движениям и идеологиям [Scholz, 2010, p. 1-2].

Большинство феминистских переводов Писания имеют в качестве методологической базы подход Г.Дж. Вермеера, согласно которому методика перевода должна зависеть от его цели; при реализации разных целей допустимы разные интерпретации текста [Munday, 2012, p. 38; Scholz, 2010, p. 4]. В инклюзивных переводах Библии реализована иная, отличная от традиционной, парадигма следования языковым нормам и использования слов и конструкций в тексте. Опираясь на принципы лингвистической концептологии, феминистские переводчики часто называют свой подход к переводам священных текстов на английский язык «культурноориентированным» [Spencer, 1997, p. 618]. Так, Д.Л. Бок и Дж. Дарт настаивают на отказе от буквализма при переводе книг Библии и переходе к методу, который вобрал бы в себя достижения исследований связи культурного контекста, исторической уместности и соответствующих переводческих тактик [Bock, 2002, p. 652; Dart, 2002, p. 11].

Цель настоящей работы - изучение лингвистических приемов перевода Библии на английский язык, выполненного в рамках феминистского дискурса, и установление адекватности результатов применения таких приемов с точки зрения классического лингвистикобогословского подхода, определение их ценности для языковедческого анализа священных текстов.

\section{Методика}

Методика исследования включает сопоставительный, структурный, сравнительноисторический методы, а также контекстный анализ. Для сопоставления с гендерно-нейтральными версиями Библии изучаются цитаты из классических переводов: оригинального издания английской Библии короля Иакова 1611 г. (King James’ Bible), елизаветинской церковнославянской Библии 1751 г. (Елизаветинская Библия), синодальной русской Библии
1876 г. (Синодальная Библия) и древнееврейского масоретского текста Танаха (Танах). При определении лексической семантики анализируемых в статье единиц использовались следующие лексикографические источники: Словарь Джонсона (1755) - архаичные английские слова и выражения (Johnson's Dictionary), Древнееврейско-русский словарь (Glosbe Dictionary), Церковнославянско-русский словарь (Церковнославянско-русский словарь).

Объект исследования - ряд наиболее известных современных английских гендернонейтральных версий Библии [Gomola, 2010, p. 207]:

- The Inclusive Bible: The First Egalitarian Translation (by Priests for Equality);

- The New Jerusalem Bible;

- The New Revised Standard Bible; version);

- The New Testament and Psalms (inclusive

- The Revised English Bible with the Apocrypha;

- Today’s New International Version.

Предмет исследования - стратегии описания Бога и божественности, атрибутов и свойств Бога в данных переводах Библии.

\section{Результаты и их обсуждение}

\section{Бог и гендерные категории}

Переосмыслить понятие божественного исходя из нового языка Библии - одна из основных задач авторов политкорректных переводов священных текстов [Flotow, 2000, p. 10; Neff, 1995, p. 19-20; O’Day, 1996, p. 692]. Их аргументация во многом сводится к тому, что Бог в классическом богословии патриархален; Он понимается как мужчина, пожилой человек, старец, отец, царь, мужчина-судья; Он именно так изображается на иконах и библейских иллюстрациях; о Нем говорится с использованием местоимений мужского грамматического рода [Cosgrove, 1993, p. 265-267; Flotow, 1991, p. 72; Halligan, 1990, p. 381-382]. Описание Бога и атрибутов божественности тесно связано в феминистском дискурсе с критикой мужского грамматического рода, а также правил его использования в английском языке [Ellis, 2003, p. 9; Martin, 1990, p. 43]. 
В Предисловии к New Jerusalem Bible указывается, что предложенный перевод отражает значительные усилия по смягчению или устранению внутренне присущей английскому языку предвзятости по отношению к маскулинности и игнорирования женских форм, в то время как слово Божье рассматривает мужчин и женщин равноправно (The New Jerusalem Bible, p. VI). Сходным образом авторы одного из переводов Библии The Revised English Bible with the Apocryphaпишут о том, что использование ориентированного на мужчин языка в традиционных английских версиях Библии в тех местах, где речь идет явно об обоих полах (гендерах), стало неприемлемой практикой с позиций современного общества и требует пересмотра (The Revised English Bible, p. IX). Во введении к The New Revised Standard Bible редактор упоминает о недопустимости в языке сексизма, с которым мы все свыклись, используя английский в повседневной речи (The New Revised Standard Bible, p. IV). Тем не менее три данные версии Библии, несмотря на постулируемое желание опираться на другие принципы английского языка, являются умеренными гендерно-нейтральными вариантами: изменение грамматических форм мужского рода ведет к пересмотру фундаментальных концепций божественности и понимания Бога.

Однако с 1994 г. в печать вышли такие инклюзивные версии Библии, как The Inclusive Bible: The First Egalitarian Translation (by Priests for Equality), Today's New International Version, The New Testament and Psalms (inclusive version), в которых авторы попытались одновременно переосмыслить как категории мужского и женского в отношении к грамматическому роду и природному полу (natural gender), так и понимание Бога, приписав Ему гендерные признаки и затем нивелировав их с помощью лингвистических конструкций.

В классических английских версиях Библии (и англиканских, и католических): King James' Bible, Wycliffe Bible, Lexham English Bible ${ }^{1}$, Douay-Rheims Bible, безусловно, используется гендерно-специфичный (неинклюзивный) язык и мужской грамматический род в тех случаях, когда подразумевается общий род. Тем не менее в Библии многократно под- черкивается, что Бог по Своей природе превосходит любые гендерные категории, находится вне и выше поля применимости концепции гендера. Говоря о Боге в мужском роде (как грамматическом, так и натуральном), классические переводы Библии не представляют Его божеством мужского пола [Biblical Revelation and Inclusive Language, 1998, p. 8]. Этим иудейское и христианское понимание Бога существенно отличается от языческого. Например, у финикийцев, живших в ближайшем соседстве с евреями в ветхозаветные времена, были божества и мужского (Ваал, Веельзевул), и женского (Астарта) пола, и финикийцы при общении с евреями не могли понять, как Бог может быть чем-то иным, не являться носителем ни мужских, ни женских черт [Poythress, 1998, p. 236]. В олимпийской греко-римской религии звучал тот же мотив присутствия пола в категориях божественного. В индуизме и древнем брахманизме также есть божества мужского и женского пола, и индуисты верят, что от их полового общения произошел мир. В даосизме и древнекитайской триграммической традиции есть духи мужского и женского начал.

Однако монотеистические религии, включая христианство, используют только описательные, условно-грамматические гендерные характеристики для выражения идей божественности, понимая, что Богу не присущи гендерные признаки per se. На Никейском Вселенском соборе 325 г. неоднократно подчеркивалось, что, говоря о Боге-Отце и Боге-Сыне и общении между ипостасями Бога, мы не имеем в виду точно того же, что подразумеваем, когда употребляем слова отеи и сын, называя людей из одной семьи [Pontifical Biblical Commission, 1993, ch. 1E]. Иларий Пиктавийский указывает, что божественное и вечное не может мыслиться в категориях пола. Григорий Нисский отмечает, что в божественной природе не содержится различения мужского и женского, как это нормально понимается в природе человеческой (цит. по: [Biblical Revelation and Inclusive Language, 1998, p. 8]).

Феминистская критика традиционного христианского понимания Бога, отраженная в лингвистических формах новых гендернонейтральных версий Библии на английском языке, по существу, не состоятельна: эти вер- 
сии Писания стараются устранить категории мужского из описания божественности, которые в традиционных переводах Библии представляют собой не более чем лингвистический (семантический) прием.

В традиционных текстах Библии можно увидеть разграничение сфер гендера и божественного. Рассмотрим несколько показательных примеров. В одной из глав Книги Чисел (Чис. 23:19) Бог говорит Валааму, сыну Beopa:

(1) God is not a man that he should lie, neither the sonne of man, that hee should repent: hath he said, and shall he not doe it? or, hath hee spoken, and shall he not make it good? (King James' Bible) Не яко человек Бог колеблется, ниже яко сын человеческий изменяется: Той глаголаше, не сотворит ли? Речет, и не пребудет ли? (Елизаветинская Библия).

Переводчики гендерно-нейтральной Библии The Inclusive Bible: The First Egalitarian Translation (by Priests for Equality), устраняя в этом фрагменте мужской грамматический род и пытаясь привести текст в соответствии с феминистской философией получают текст, в котором исходный смысл о том, что Бог не есть мужчина, элиминирован:

(2) God is not a human, able to lie, nor the offspring of humans, capable of retracting a promise. does God speak and then not act? does God promise and not fulfill? (The Inclusive Bible).

В Чис. 23:19 Бог не просто противопоставляет Себя человеческой сути, но и свидетельствует о том, что Он не является носителем мужских черт. Как мы видим, это хорошо отражено в классической Библии короля Иакова, но стерто в гендерно-нейтральной Inclusive Bible.

В книге пророка Осии (Ос. 11:9) сходным образом Бог дает знать человеку о Своей надчеловеческой и немужской природе:

(3) I will not execute the fiercenes of mine anger, I will not returne to destroy Ephraim, for I am God, and not man, the Holy One in the midst of thee, and I will not enter into the citie (King James' Bible). - He coтворю по гневу ярости Моея, не оставлю еже потребитися Ефремови, зане Бог Аз есмь, а не человек: в тебе Свят, и не вниду во град (Елизаветинская Библия).
Отрывок из Исайи (Ис. 55:8) тоже свидетельствует о том, что Бог имеет принципиально отличную от человека природу вне сферы гендера:

(4) For my thoughts are not your thoughts, neither are your wayes my wayes, saith the Lord (King James' Bible). - Не суть бо совети Мои якоже совети ваши, ниже якоже путие ваши путие Мои, глаголет Господь (Елизаветинская Библия).

Во всех приведенных фрагментах божественное откровение свидетельствует о различении сущности Бога и человека. Следовательно, такие номинации Бога, как Отещ, Царь или Жених, - это метафора. Она проявляется и при визуализации: Бог-Отец изображен на иконах и фресках как седовласый старец лишь условно. Это предоставляет пространство для дальнейших политкорректных допущений в рамках феминистского дискурса. Если мы, говоря о Боге и рассуждая о категориях божественности, оперируем языковыми метафорами старца, пожилого мужчины для описания внегендерного Бога, то не можем ли мы сходным образом изображать Его женщиной (пожилой или молодой, белой или черной - не имеет значения) для достижения эгалитаризма и равноправия полов [Johnson, 1999, p. 3; Kimbrough, 1989, p. 197]? Феминистский посыл достаточно ясен: раз Бог находится за пределами сферы гендера, то почему мы должны обязательно использовать патриархальные категории для Его вербального и визуального представления? Не будут ли феминные категории столь же уместными [Blomberg, 2005, p. 201; Mollenkott, 1994, p. 47; The Liberating Word..., 1977, p. 28]?

\section{Представление Бога в метафорах женского рода}

Р.С. Гесс и С.Т. Кимбро, одобряя радикально гендерно-нейтральные версии английской Библии, указывают, что, думая о Боге, человек не должен всякий раз понимать Его в патриархальном смысле как «ветхого днями» старца, ему следует также часто мыслить и рассуждать о Нем как о воображаемой женщине, пожилой или молодой [Hess, 2005, p. 145; Kimbrough, 1989, p. 199]. 
Н. Хардести задается вопросом, можем ли мы говорить о Боге не только как об Отце, но как об Отце и Матери (см. гендерно-нейтральный перевод Библии The New Testament and Psalms (inclusive version) 1995 г.), ведь в ряде библейских текстов Бог представлен в женских категориях: поскольку использованы метафоры материнства и воспитания детей [Hardesty, 1988, p. 234]? В ее работе приводятся цитаты Ис. 44:2, 24, 46: 3-4, 49:1, 5 и Иер. $1: 5$, где говорится о том, что Бог создал человека от своего чрева, ложесн (матки) или утробы (wombe и bellie в Библии короля Иакова), что могло бы свидетельствовать в пользу легитимности изображения Бога как Матери людей [Hardesty, 1988, p. 235]. М. Грубер в своей статье «Материнство Бога у второго Исайи» отмечает, что пророк Исайя несколько раз приводит явные сравнения Бога с женщиной-матерью: Ис. 42:13, 45:10, 49:14, 66:13 [Gruber, 1983, p. 354].

Полагаем, что феминистская аргументация здесь разнопланова и не совсем корректна. В приведенных Грубером цитатах из Исайи применен прием сравнения, но ни в одной из них не говорится о Боге как существе, которое может быть изображено или воображено существом женского пола, в эссенциалистском, то есть сущностном смысле. Например, в Ис. 66:13 сказано:

(5) As one whom his mother comforteth, so wil I comfort you: and ye shall be comforted in Ierusalem (King James' Bible). - Якоже аще кого мати утешает, тако и Аз утешу вы, и во Иерусалиме утешитеся (Елизаветинская Библия).

Однако это стандартный языковой прием сравнения; он не выражает эссенциалистских свойств того, кого сравнивают с чемлибо или кем-либо. Например, когда говорится хитрый, как лиса, не имеется в виду, что человека можно вообразить лисицей и он начнет рожать лисят; фраза поезд быстрый, как ветер вовсе не означает, что поезд перестает везти людей, дематериализуется и превращается в несущийся дальше поток воздуха. В русском языке постановка запятой перед союзом как сигнализирует о сравнении; ее отсутствие - о том, что говорится о персоне как о ком-либо или чем-либо, имеется в виду ее природа (то есть качество). В английском языке такой пунктуационной подсказки, правда, нет.

В аргументации Н. Хардести значительное место занимает концептуальное овеществление Бога как рождающей Матери; исследователь ссылается на использование в речи пророков лексических единиц, характеризующих деторождение. Безусловно, слова wombe и bellie в английской Библии короля Иакова дают возможность такой интерпретации: Бог произвел (родил) человека из Своего собственного чрева. Однако полагаем, что подобное толкование поверхностно. Говорит ли Бог через пророков Исайю и Иеремию, что он так же, как женщина, родил первых людей из Своей утробы? Думается, нет. У Иеремии читаем (Иер. 1:5):

(6) Before I formed thee in the bellie, I knew thee; and before thou camest forth out of the wombe, I sanctified thee, and I ordeined thee a Prophet vnto the nations (King James' Bible). - Прежде неже мне создати тя во чреве, познах тя, и прежде неже изыти тебе из ложесн, освятих тя, пророка во языки поставих тя (Елизаветинская Библия).

В этом стихе не используются притяжательные местоимения my или mine (мой); Бог говорит не *I formed thee in my bellie (Я создал тебя в Моем чреве), а I formed thee in the bellie (Я создал тебя во чреве); не *thou camest forth out of my wombe (ты вышел из Моей утробы), а thou camest forth out of the wombe (ты вышел из утробы). Если принять во внимание тот факт, что в английском языке притяжательные местоимения употребляются намного чаще, чем в славянских языках, а также буквализм перевода Библии короля Иакова с древнееврейского оригинала, то можно предположить следующее: отсутствие притяжательных местоимений в процитированном отрывке свидетельствует о том, что речь идет не о чреве Бога, а о чреве матери пророка Иеремии. Следовательно, предложенное Н. Хардести истолкование слов Иеремии как описание рождения Богом человека из Своего чрева несостоятельно.

Не подтверждается и предположение Н. Хардести о рождении человека Богом как некой всеобщей Матерью мира и человечества. В Ис. 49:1 прямо говорится о том, что Бог призвал пророка Исайю от чрева его матери: 
(7) Listen, O yles, vnto me, and hearken yee people from farre. The Lord hath called mee from the wombe, from the bowels of my mother hath he made mention of my name (King James' Bible). - Слушайте Меня, острова, и внимайте, народы дальние: Господь призвал Меня от чрева, от утробы матери Моей называл имя Мое (Синодальная библия).

Здесь, помимо слова wombe (утроба), используется редкое в King James' Bible слово bowels (внутренность), но ясно сказано, что имеется в виду мать Исайи (my mother). 46-я глава книги Исайи (Ис. 46:3, 46:4) дает несколько большие возможности для феминистских интерпретаций:

(8) Hearken vnto me, O house of Iacob, and al the remnant of the house of Israel, which are borne by me, from the belly, which are caried from the wombe (King James' Bible). - Послушайте Мене, доме Иаковль и весь останок Израилев, носимии от чрева и наказуемии от детска даже до старости (Елизаветинская Библия);

(9) And euen to your old age I am he, and euen to hoare haires will I cary you: I haue made, and I will beare, euen I wil cary and wil deliuer you (King James' Bible). - Аз есмь, и дондеже состареетеся, Аз есмь, Аз терплю вам, Аз сотворих и Аз понесу, Аз подиму и спасу вы (Елизаветинская Библия).

Н. Хардести настаивает на том, что глагол to beare во фразе $O$ house of Iacob, and al the remnant of the house of Israel, which are borne by me, from the belly означает «рождать», а не «носить», и тогда возникает иной смысл: «которые рождены Мной». В древнееврейском оригинале читаем:

(Танах, Ис. 46:3)

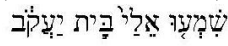

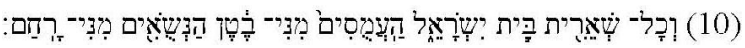

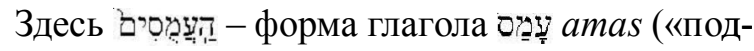
нимать бремя, нести, навьючивать на себя, нагружать на себя»); она переведена в Библии короля Иакова как borne (причастие II от глагола to beare), которое не реализует значе-

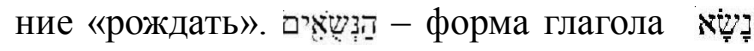
nasa («поднимать, нести, возвышать»). Она переведена в King James'Bible как are caried, форма английского глагола to cary, которая также не выражает значения «производить на свет», «рождать». Буквалистский перевод
Библии короля Иакова 1611 г. позволяет предположить, что в данном контексте оба использованных глагола (to cary и to beare) означают одно и то же - «носить ношу, поднимать груз, возвышать нечто», поэтому глагол to beare не может переводиться как «рождать» (to give birth), хотя он может реализовать это значение в других контекстах. Отметим, что в греческом Переводе семидесяти толковников смысл передан не столь буквально, как в King James' Bible: слово הַנְשֶׁים «носимые» в Септуагинте трансформировалось в $\pi \alpha 1 \delta \varepsilon v o ́ \mu \varepsilon v o l$, причастную форму глагола $\pi \alpha 1 \delta \varepsilon v ́ \omega$ («воспитывать, наставлять, дисциплинировать»).

Приводимые Н. Хардести выдержки из 44 главы Книги пророка Исайи имеют некоторые новые, не менее интересные лингвистические коннотации: в стихе Ис. 44:2 читаем:

(11) Thus sayeth the Lord that made thee, and formed thee from the wombe, which wil helpe thee: Feare not, O Iacob, my seruant, and thou Iesurun ${ }^{2}$, whom I haue chosen (King James' Bible). - Сице глаголет Господь Бог сотворивый тя и создавый тя из утробы: еще поможет ти: не бойся, рабе Мой Иакове, и возлюбленный Израилю, егоже избрах (Елизаветинская Библия);

а в стихе Ис. 44:24 находим:

(12) Thus saith the Lord thy redeemer, and he that formed thee from the wombe; I am the Lord that maketh all things, that stretcheth forth the heauens alone, that spreadeth abroad the earth by my selfe (King James' Bible). - Сице глаголет Господь избавляяй тя и создавый тя от чрева: Аз Господь совершаяй вся, распрострох небо един и утвердих землю (Елизаветинская Библия).

В обоих отрывках употреблено словосочетание to forme from the wombe («сотворить от утробы, создать от чрева»). Можно ли считать его синонимом словам со значением «родить», которое отсылало бы к пониманию Бога как Матери, родившей человечество? Достаточно литеральная Библия короля Иакова, ориентированная не на Септуагинту, а на древнееврейский подлинник, точно передает семантические оттенки оригинала, ср. Ис. 44:2 и 44:24 в древнееврейском тексте: 


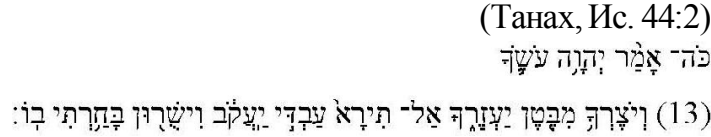

(Танах, Ис. 44:24)

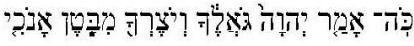

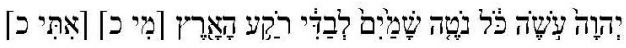

(14)

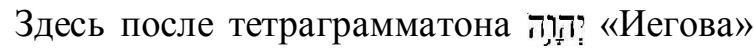
в обоих контекстах использованы формы, соединенные союзом: в Ис. 44:2 это формы

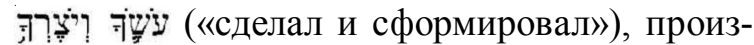
водные от глаголов

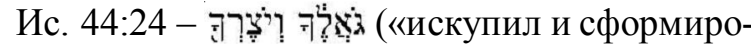

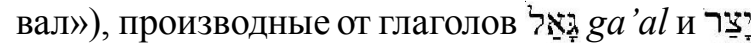
yatsar. Asah («делать, приготовлять, производить») эквивалентно англ. to make, ga 'al («избавлять, спасать, искупать») - англ. to redeeme; yatsar («формировать, образовывать») - англ. to forme в значении «придавать форму» (как горшечник формирует глину или скульптор ваяет статую, но не как эмбрион во чреве матери становится ребенком, человеком).

Видимо, в древнееврейском оригинале заложена идея формирования человека Богом в утробе (недрах) земли ${ }^{3}$ (как если бы Бог, как некий горшечник, некий гончар, сформировал первого человека из глины), а не идея рождения человека из утробы Бога. Для обозначения процесса рождения младенца из утробы матери в древнееврейском существовал глагол ללדת laledith, но у Исайи это слово не использовано ни разу, как и глагол 글 bara («сотворить из ничего»), который встречается у Моисея в первой фразе Библии при описании сотворения Богом мира. В Священном Писании в подавляющем большинстве фрагментов, где речь идет о творении, созданном человеком, употребляется слово 플 yatsar «сотворить из чего-либо, из некого подручного материала», то есть как мастер творит свое произведение. В этом нет противоречия с другими стихами Библии: Бог сформировал человека из земли (Быт. 2:7):

(15) And the Lord God formed man of the dust of the ground, and breathed into his nostrils the breath of life; and man became a liuing soule (King James' Bible). - И созда Бог человека, персть (взем) от зем- ли, и вдуну в лице его дыхание жизни: и бысть человек в душу живу (Елизаветинская Библия).

В древнееврейском тексте, как в английском и церковнославянском, используется сочинительный союз и форма прошедшего времени единственного числа мужского рода глагола yatsar со значением «формирование, образование»:

(Танах, Быт. 2:7)

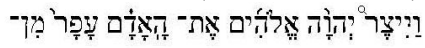

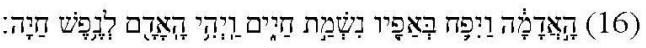

В контексте феминистского дискурса о возможности описания Бога в женских категориях, как утверждают Э. Стэнтон [Stanton, 2003, p. 117], М. Уокер [Walker, 1989, p. 12], С. Шрер и С. Битенхард [Schroer, Bietenhard, 2003, p. 140], представляет интерес отрывок из Второзакония (Втор. 32:18), где, по их мнению, Бог говорит о Себе в женских категориях:

(17) Of the Rocke that begate thee thou art vnmindfull, and hast forgotten God that formed thee (King James' Bible). - a Заступника, родившего тебя, ты забыл, и не помнил Бога, создавшего тебя (Синодальная Библия).

Ни церковнославянский, ни английский тексты полностью не передают смысла древнееврейского оригинала, к которому апеллируют упомянутые авторы. Рассмотрим этот фрагмент. В масоретском тексте Танаха он представлен следующим образом:

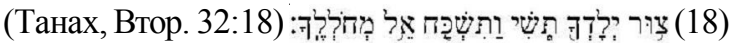

Бог уподобляется Скале, которая родила народ израильский: глагол to begete («рождать, производить на свет») в английском переводе короля Иакова - верный аналог древнееврейского глагола '?ר yalad. Точка зрения упомянутых исследователей, казалось бы, подтверждается тем, что последняя глагольная форма в древнееврейском тексте - это חוּל khul («мучиться в родах, корчиться в родовых муках, трепетать»). Значит, §אֵֶ это дословно - «Бог $(e l)$, корчившийся в муках рождения». Можем ли мы говорить о Боге не как об Отце, но как об Отце и Матери, ис- 
ходя из этой фразы? Дать однозначный ответ на этот вопрос невозможно. Па'аль-форма глагола yalad выражает значение «рожать», «давать рождение» и является синонимом глагола laledith. Однако yalad в древнееврейском отличается от laledith так же, как в английском глагол to beget от to give birth. Лексические единицы laledith, to give birth употребляются только по отношению к рожающей женщине, в то время как yalad, to beget - и к матери, и к отцу, например: Abraham begate Isaac (Авраам родил Исаака). Показательно, что в Библии короля Иакова употребляется to begete, а не to give birthe. Безусловно, «корчиться в муках» может только мать, но если принять во внимание то, что апостол Павел пишет в послании Галатам о себе как о человеке, находящемся в муках роженицы

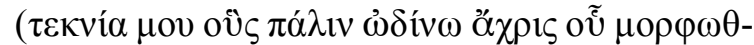

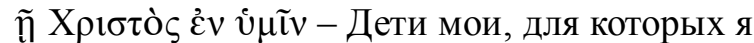
снова в муках рождения, доколе не изобразится в вас Христос!), то возможно трактовать Втор. 32:18 как яркую метафору ${ }^{4}$, которую Моисей использует для того, чтобы сильно подействовать на огрубевшие сердца древних евреев, которые отказались от Бога, выведшего их из Египта.

\section{Заключение}

Предложенное в статье исследование библейских текстов не позволяет представлять Бога Матерью, воображать Его в сознании и изображать на фресках / иконах в облике женщины. Кроме Втор. 32:18, в Писании не обнаруживается каких-либо сравнений Бога с женщиной. В гендерно-нейтральных версиях Библии исключение грамматических форм мужского рода из стихов, посвященных описанию Бога и категорий божественности, и добавление в некоторых случаях феминных смыслов изменяют не только зафиксированное в священных текстах с древних времен представление о Самом Боге, но также влияют на наше понимание взаимоотношения Бога с миром, который Он сотворил. В языческих культах мир часто изображается порожденным утробой некого божества женского пола, что неизбежно приводит к пантеизму, поскольку мир неявным образом продолжает оставаться ча- стью символического тела женского божества. Однако в рамках христианского дискурса утверждается, что Бог сотворил Вселенную из ничего, не произвел из своего чрева, а именно создал в результате творческого акта по Своей свободной воле.

В результате изменения языка Библии не только отражается эгалитаризм и равноправие полов, но и неизбежно искажаются богословско-исторические контексты, подменяются содержащиеся в Библии исходные смыслы иными смыслами, возможно, более привлекательными с социальной точки зрения. Волюнтаристские политкорректные изменения текстов Библии, касающихся описаний Бога, свойств и атрибутов божественности, нельзя проводить по четырем причинам:

1) язык Писания - не только дескриптивный инструмент для передачи библейских историй Ветхого и Нового Завета, это еще и язык откровения, которым, как полагают верующие иудеи, христиане и мусульмане, Сам Бог разговаривал с пророками, апостолами и учениками, следовательно, при изменении языка существенно меняется смысл послания;

2) в иудаизме, христианстве и мусульманстве утверждается, что Бог находится вне сферы гендера и не может отождествляться с мужским или женским началом мира, как это происходит во многих языческих религиях; описание Бога в мужских терминах условно и тесно связано с библейскими метафорами и конвенциями древнееврейского языка, а также с откровением Бога о Себе Самом, зафиксированном в языковых конструкциях;

3) Библия короля Иакова представляет собой точный литеральный английский перевод древних священных текстов, который хорошо передает контекст; современные гендерно-нейтральные версии Библии не обогащают академическое богословие, не расширяют возможностей исторического анализа древних обществ - израильского и соседних с ним народов (персов, вавиловян, ассирийцев, хеттов, финикийцев, арабов, греков, римлян и т. п.);

4) Христос воплотился в человеческом теле как мужчина (это не может подвергаться сомнению), Он говорил о Боге как об Отце 
и Он говорил о Себе как о Боге и Сыне, что передано словами со значением «отец» (אבא $a b b a)$ и «сын» (בן ben), а не словами со значением «мать» и «дочь» или «отец с матерью» и «сын»; значит, ветхозаветное рассуждение о Боге в мужских терминах имеет дополнительный пласт богословских смыслов, которые оправдывают использование лингвистического мужского рода и мужского натурального гендера, связанного с метафорами и языковыми контекстами Библии.

Лингвистика, таким образом, оказывается неразрывно связанной с богословскими толкованиями Писания; использование лингвистического инструментария приводит нас к различному пониманию Бога и Его свойств. Феминизм как борьба за равноправие женщин - явление позитивное и для общества нужное. Однако использование феминистского дискурса в рассуждениях о Боге, утверждающего, что Он содержит одновременно мужское и женское начала, неизбежно приводит читателя таких текстов к заблуждениям, а в крайних случаях - к ересям манихейско-зороастрийского толка. Каких бы идеологических принципов ни придерживался переводчик Библии, ему следует помнить о том, что ее язык обладает надвременным характером, а Бог - надчеловеческими свойствами, и любой перевод Писаний, игнорирующий эти особенности в угоду злободневным политическим, социальным и культурным предпочтениям, обречен на искажения библейского смысла.

\section{ПРИМЕЧАНИЯ}

${ }^{1}$ Lexham Bible - современный перевод текстов Библии на английский язык, который, однако, является одним из наиболее буквалистских: в этой Библии поэтика и стройность слога вторичны по отношению к жесткому следованию переводческой схеме «слово за слово».

2 Jesurun, Iesurun, Jeshurun (Ешерон, Иешурун) - поэтическое название Израиля, используемое в некоторых местах Ветхого Завета.

${ }^{3}$ Примечательно, что в английском языке слово bowels (недра) используется для обозначения и внутренностей человека, и недр земли.

${ }^{4}$ Метафора роженицы широко использовалась в древнем мире по отношению как к женщине, так и мужчине и вне библейского контекста. Философ Сократ, например, употреблял метафору мук деторождения, в которых пребывают мужи, рождающие истину, себя называл акушером, а свое искусство ведения диалога - майевтикой, акушерским занятием.

\section{СПИСОК ЛИТЕРАТУРЫ}

An Inclusive Language Lectionary, 1985. Philadelphia, PA: Westminster Press. 264 p.

Bibel in gerechter Sprache, 2006. Gütersloh : Gütersloher Verlagshaus. 1856 S.

Biblical Revelation and Inclusive Language. A Report of the Commission on Theology and Church Relations of the Lutheran Church - Missouri Synod, 1998. URL: https://www.lcms.org/ Document.fdoc? $\mathrm{src}=\mathrm{lcm} \& \mathrm{id}=314$ (accessed 30 September 2018).

Blomberg C. L., 2005. Today's New International Version: The Untold Story of a Good Translation // The Bible Translator. Vol. 56, no. 3. P. 187-211.

Bock D. L., 2002. Do Gender-Sensitive Translations Distort Scripture? Not Necessarily // Journal of the Evangelical Theological Society. Vol. 45, no. 4. P. 651-669.

Brenner A., Fontaine C., 2001. A Feminist Companion to Reading the Bible: Approaches, Methods and Strategies. London; Chicago : Fitzroy Dearborn. $654 \mathrm{p}$.

Cosgrove Ch. H., 1993. The First Attempt to Use Gender-Inclusive Language in English Bible Translation // Journal of Ecumenical Studies. Vol. 30, no. 2. P. 263-268.

Dart J., 2002. Gender and the Bible: Evangelical Wrangle Over New Translation // Christian Century. Vol. 119, no. 14. P. 11-13.

Ellis E. E., 2003. Dynamic Equivalence Theory, Feminist Ideology, and Three Recent Bible Translations // Expository Times. Vol. 115, no. 1. P. 7-12.

Flotow L. von, 1991. Feminist Translation: Contexts, Practices and Theories // TTR: Traduction, terminologie, redaction. Vol. 4, no. 2. P. 69-84.

Flotow L. von, 2000. Women, Bibles, Ideologies // TTR: traduction, terminologie, redaction. Vol. 13, no. 1 . P. 9-20.

Gomola A., 2010. Feminist thought in Bible translations // Przekładaniec. A Journal of Literary Translations. Vol. 24. P. 193-208. DOI: 16891864ePC.12.009.0571.

Gruber M. I., 1983. The Motherhood of God in Second Isaiah // Revue Biblique. Vol. 90. P. 351-359.

Halligan F., 1990. WomanChurch: Toward a New Psychology of Feminine Spirituality // Pastoral Care. Vol. 44, no. 4. P. 379-389.

Hardesty N. A., 1988. 'Whosoever Surely Meaneth Me': Inclusive Language and the Gospel // Christian Scholar's Review. Vol. 17, no. 3. P. 231-240. 
Harrelson W., 1991. Inclusive Language in the New Revised Standard Version // The Making of the New Revised Standard Version of the Bible / B. M. Metzger, R. C. Dentan, W. Harrelson (eds.). Grand Rapids, MI : Eerdmans. 92 p.

Hess R. S., 2005. Adam, Father, He: Gender Issues in Hebrew Translation // The Bible Translator. Vol. 56, no. 3. P. 144-153.

Jacobs M. M., 2001. Feminist scholarship, biblical scholarship and the Bible // Neotestamentica. Vol. 35, no. 1-2. P. 81-94.

Johnson E., 1999. She Who Is: The Mystery of God in Feminist Theological Discourse. New York : Crossroad. 344 p.

Kimbrough S. T., 1989. Theological Table-Talk: Bible Translation and the Gender of God // Theology Today. Vol. 46, no. 2. P. 195-202.

Kittel G., Friedrich G., 2003. Theological Dictionary of the New Testament. Grand Rapids, MI : W.B. Eerdmans. 1392 p.

Martin C. J., 1990. Womanist Interpretations of the New Testament: The Quest for Holistic and Inclusive Translation and Interpretation // Journal ofFeminist Studies in Religion. Vol. 6, no. 2. P. 41-61.

Mollenkott V., 1994. The Divine Feminine: The Biblical Imagery of God as Female. New York : Crossroad Publication. $120 \mathrm{p}$.

Munday J., 2012. Introducing Translation Studies: Theories and Applications. London : Routledge. 384 p.

Neff D., 1995. Lost in the Translation: Can the New Inclusive Bible's Human One, Child of FatherMother God, Save Us? // Christianity Today. Vol. 39, no. 2. P. 19-25.

O’Day G. R., 1996. Probing an Inclusive Scripture // Christian Century. No. 3. P. 692-694.

Pontifical Biblical Commission, 1993. The Interpretation of the Bible in the Church. URL: http://catholicresources.org/ChurchDocs/PBC_Interp1.htm (accessed 20 October 2018).

Poythress V. S., 1998. Gender in Bible Translation: Exploring a Connection with Male Representatives // Westminster Theological Journal. Vol. 60. P. 225-253.

Scholz S., 2010. The Bible as "Men's World"? Feminism and the translation of the Hebrew Bible // Lectio Difficilior. No. 1. P. 1-43.

Schroer S., Bietenhard S., 2003. Feminist Interpretation of the Bible and the Hermeneutics of Liberation. London : Sheffield Academic Press. 178 p.

Spencer A. B., 1997. Power Play: Gender Confusion and the NIV // Christian Century. Vol. 114, no. 20. P. 618-619.

Stanton E. C., 2003. The Woman's Bible: AClassicFeminist Perspective. Mineola, New York : Dover. 384 p.

The Liberating Word: A Guide to Nonsexist Interpretation of the Bible, 1977. L. M. Russell (ed.). Philadelphia, PA : Westminster Press. $121 \mathrm{p}$.

Walker M., 1989. The Challenge of Feminism to the Christian Concept of God // Journal of Theology for Southern Africa. Vol. 66. P. 4-20.

Walsh M. P., 1999. Feminism and Christian Tradition. An Annotated Bibliography and Critical Introduction to the Literature. Westport, CT : Greenwood. $472 \mathrm{p}$.

\section{ИСТОЧНИКИ И СЛОВАРИ}

Елизаветинская Библия - Бібліа сирҺчь Книги Сщеннагш Писанія Ветхагш и Новагш Зав ьта. Санктпетербургъ : Ея Императорскагळ Величества Т ипографія, $1751.3624 \mathrm{c}$.

Синодальная Библия - Біблія. Санкт-Петербургъ : Т vпографія Священнаго С ннода, 1876. 2440 с.

Церковнославянско-русский словарь - Полный церковно-славянский словарь. С внесением в него важнейших древнерусских слов и выражений. URL: http://www.orthodic.org.

Tанах - Tanakh. Editio Iacobi ben Chajjim. Regensburg : Hr Rotman, 1556. 2682 S.

Glosbe Dictionary - Древнееврейско-русский словарь. URL: https://ru.glosbe.com/hbo/ru.

Johnson's Dictionary - A Dictionary of the English Language in which the Words are Deduced from Their Originals, and Illustrated in Their Different Significations by Examples from the Best Writers. In 2 vols. London : J.F. Rivington, 1755.

King James' Bible - The Holy Bible, Conteyning the Old Testament, and the New: Newly Translated out of the Originall Tongues: And with the Former Translations Diligently Compared and Reuised, by His Maiecties Special Comandement. Appointed to Be Read in Churches. London : Robert Barker, 1611. $1504 \mathrm{p}$

The Inclusive Bible - The Inclusive Bible: The First Egalitarian Translation (by Priests for Equality). New York : Sheed \& Ward, 2009. 808 p.

The New Jerusalem Bible - The New Jerusalem Bible. Garden City, New York: Doubleday, 1985.2108 p.

The New Revised Standard Bible - The New Revised Standard Bible. Grand Rapids, MI : Zondervan, 2009. 1536 p.

The New Testament and Psalms - The New Testament and Psalms (inclusive version). Oxford : Oxford University Press, 1995. 535 p.

The Revised English Bible - The Revised English Bible with the Apocrypha. New Rochelle, New York : Oxford University Press ; Cambridge University Press, 1989. 1269 p.

Today's New International Version - Today's New International Version. Grand Rapids, MI : Zondervan, 2005. $1184 \mathrm{p}$. 


\section{REFERENCES}

An Inclusive Language Lectionary, 1985. Philadelphia, PA, Westminster Press. 264 p.

Bibel in gerechter Sprache, 2006. Gütersloh, Gütersloher Verlagshaus. 1856 S.

Biblical Revelation and Inclusive Language. A Report of the Commission on Theology and Church Relations of the Lutheran Church - Missouri Synod, 1998. URL: https://www.lcms.org/ Document. $f d o c ? \mathrm{src}=1 \mathrm{~cm} \& \mathrm{id}=314$ (accessed 30 September 2018).

Blomberg C.L., 2005. Today's New International Version: The Untold Story of a Good Translation. The Bible Translator, vol. 56, no. 3, pp. 187-211.

Bock D.L. 2002. Do Gender-Sensitive Translations Distort Scripture? Not Necessarily. Journal of the Evangelical Theological Society, vol. 45, no. 4, pp. 651-669.

Brenner A., Fontaine C., 2001. A Feminist Companion to Reading the Bible: Approaches, Methods and Strategies. London, Chicago, Fitzroy Dearborn. $654 \mathrm{p}$.

Cosgrove Ch.H., 1993. The First Attempt to Use Gender-Inclusive Language in English Bible Translation. Journal of Ecumenical Studies, vol. 30, no. 2, pp. 263-268.

Dart J., 2002. Gender and the Bible: Evangelical Wrangle Over New Translation. Christian Century, vol. 119, no. 14, pp. 11-13.

Ellis E.E., 2003. Dynamic Equivalence Theory, Feminist Ideology, and Three Recent Bible Translations. Expository Times, vol. 115, no. 1, pp. 7-12.

Flotow L. von, 1991. Feminist Translation: Contexts, Practices and Theories. TTR: Traduction, Terminologie, Redaction, vol. 4, no. 2, pp. 69-84.

Flotow L. von, 2000. Women, Bibles, Ideologies. TTR: Traduction, Terminologie, Redaction, vol. 13, no.1, pp. 9-20.

Gomola A., 2010. Feminist Thought in Bible Translations. Przekiadaniec. A Journal of Literary Translations, vol. 24, pp. 193-208. DOI: 16891864ePC.12.009.0571.

Gruber M.I., 1983. The Motherhood of God in Second Isaiah. Revue Biblique, vol. 90, pp. 351-359.

Halligan F., 1990. WomanChurch: Toward a New Psychology of Feminine Spirituality. Pastoral Care, vol. 44, no. 4, pp. 379-389.

Hardesty N.A., 1988. 'Whosoever Surely Meaneth Me': Inclusive Language and the Gospel. Christian Scholar's Review, vol. 17, no. 3, pp. 231-240.

Harrelson W., 1991. Inclusive Language in the New Revised Standard Version. Metzger B.M., Dentan R.C., Harrelson W., eds. The Making of the New Revised Standard Version of the Bible. Grand Rapids, MI, Eerdmans. 92 p.
Hess R.S., 2005. Adam, Father, He: Gender Issues in Hebrew Translation. The Bible Translator, vol. 56, no. 3, pp. 144-153.

Jacobs M.M., 2001. Feminist Scholarship, Biblical Scholarship and the Bible. Neotestamentica, vol. 35, no. 1-2, pp. 81-94.

Johnson E., 1999. She Who Is: The Mystery of God in Feminist Theological Discourse. New York, Crossroad. $344 \mathrm{p}$.

Kimbrough S.T., 1989. Theological Table-Talk: Bible Translation and the Gender of God, Theology Today, vol. 46, no. 2, pp. 195-202.

Kittel G., Friedrich G., 2003. Theological Dictionary of the New Testament. Grand Rapids, MI, W. B. Eerdmans. 1392 p.

Martin C.J., 1990. Womanist Interpretations of the New Testament: The Quest for Holistic and Inclusive Translation and Interpretation. Journal of Feminist Studies in Religion, vol. 6, no. 2, pp. 41-61.

Mollenkott V., 1994. The Divine Feminine: The Biblical Imagery of God as Female. New York, Crossroad Publication. $120 \mathrm{p}$.

Munday J., 2012. Introducing Translation Studies: Theories and Applications. London, Routledge. $384 \mathrm{p}$.

Neff D., 1995. Lost in the Translation: Can the New Inclusive Bible's Human One, Child of FatherMother God, Save Us? Christianity Today, vol. 39, no. 2, pp. 19-25.

O’Day G.R., 1996. Probing an Inclusive Scripture. Christian Century, no. 3, pp. 692-694.

Pontifical Biblical Commission. The Interpretation of the Bible in the Church, 1993. URL: http:// catholic-resources.org/ChurchDocs/ PBC_Interp1.htm (accessed 20 October 2018).

Poythress V.S., 1998. Gender in Bible Translation: Exploring a Connection with Male Representatives. Westminster Theological Journal, vol. 60, pp. 225-253.

Scholz S., 2010. The Bible as "Men's World"? Feminism and the translation of the Hebrew Bible. Lectio Difficilior, no. 1, pp. 1-43.

Schroer S., Bietenhard S., 2003. Feminist Interpretation of the Bible and the Hermeneutics of Liberation. London, Sheffield Academic Press. 178 p.

Spencer A.B., 1997. Power Play: Gender Confusion and the NIV. Christian Century, vol. 114, no. 20, pp. 618-619.

Stanton E.C., 2003. The Woman's Bible: A Classic Feminist Perspective. Mineola, New York, Dover. $384 \mathrm{p}$.

Russell L.M., ed., 1977. The Liberating Word: A Guide to Nonsexist Interpretation of the Bible. Philadelphia, PA, Westminster Press. $121 \mathrm{p}$.

Walker M., 1989. The Challenge of Feminism to the Christian Concept of God. Journal of Theology for Southern Africa, vol. 66, pp. 4-20. 
Walsh M.P., 1999. Feminism and Christian Tradition. An Annotated Bibliography and Critical Introduction to the Literature. Westport, CT, Greenwood. $472 \mathrm{p}$.

\section{SOURCES AND DICTIONARIES}

Bibliya sirech Knigi Sshchennago Pisaniya Vetkhago i Novago Zaveta., 1751. Saint Petersburg, Eya Imperatorskago Velichestva Tipografiya. $3624 \mathrm{p}$.

Bibliya., 1876. Saint Petersburg, Tipografiya Svyashhennago Sinoda. 2440 c.

Polnyy tserkovno-slavyanskiy slovar. S vneseniem v nego vazhneyshikh drevnerusskikh slov $i$ vyrazheniy [Full Church Slavonic Dictionary. With the Most Important Old Russian Words and Expressions]. URL: http://www.orthodic.org. Tanakh. Editio Iacobi ben Chajjim, 1556. Regensburg, Hr Rotman Publ. 2682 S.

Drevneevreysko-russkiy slovar [Hebrew-Russian Dictionary]. URL: https://ru.glosbe.com/hbo/ru.

A Dictionary of the English Language in Which the Words are Deduced from Their Originals, and
Illustrated in Their Different Significations by Examples from the Best Writers, 1755. London, J.F. Rivington.

The Holy Bible, Conteyning the Old Testament, and the New: Newly Translated out of the Originall Tongues: And with the Former Translations Diligently Compared and Reuised, by His Maiecties Special Comandement. Appointed to Be Read in Churches, 1611. London, Robert Barker Publ. 1504 p.

The Inclusive Bible: The First Egalitarian Translation (By Priests for Equality), 2009. New York, Sheed \& Ward. $808 \mathrm{p}$.

The New Jerusalem Bible, 1985. Garden City, New York, Doubleday. 2108 p.

The New Revised Standard Bible, 2009. Grand Rapids, MI, Zondervan. $1536 \mathrm{p}$.

The New Testament and Psalms (Inclusive Version), 1995. Oxford, Oxford University Press. 535 p.

The Revised English Bible with the Apocrypha, 1989. New Rochelle, New York, Oxford University Press, Cambridge University Press. 1269 p.

Today's New International Version, 2005. Grand Rapids, MI, Zondervan. 1184 p.

\section{Information about the Author}

Konstantin S. Sharov, Candidate of Sciences (Philosophy), Senior Lecturer, Philosophy Department, M.V. Lomonosov Moscow State University, Prosp. Lomonosovsky, 27, Bld. 4, 119991 Moscow, GSP-1, Russia, const.sharov@mail.ru,https://orcid.org/0000-0003-4784-0333

\section{Информация об авторе}

Константин Сергеевич Шаров, кандидат философских наук, старший преподаватель, философский факультет, Московский государственный университет им. М.В. Ломоносова, просп. Ломоносовский, 27, корп. 4, 119991 г. Москва, ГСП-1, Россия, const.sharov@mail.ru, https://orcid.org/0000-0003-4784-0333 